\title{
TREATED OIL PALM FROND AND ITS UTILISATION AS AN IMPROVED FEEDSTUFF FOR RUMINANTS - AN OVERVIEW
}

\author{
MOOKIAH SAMINATHAN ${ }^{1 *}$; WAN NOORAIDA WAN MOHAMED'; 'ABIDAH MD NOH'; \\ NUR ATIKAH IBRAHIM'; MUHAMMAD AMIRUL FUAT'; SURIYA KUMARI RAMIAH²; \\ ERIC LIM TEIK CHUNG ${ }^{3}$ and NOOR LIDA HABI MAT DIAN ${ }^{1}$
}

\begin{abstract}
Oil palm frond (OPF) is a biomass residue from oil palm plantations that have received increasing interest for its promise as roughage resources to overcome limitations of ruminant feeding. However, the use of OPF for livestock productivity is limited by its high lignocellulosic content and low nutritional value. Various physical, chemical, biological and physico-chemical treatments have been used to improve the nutritional value of OPF. This review was conducted to study the treatment methods of OPF as a value-added feedstuff and emphasise the effects of treated OPF on in vitro ruminal fermentation and in vivo ruminant digestibility and growth performance. The biological treatment produced favourable outcomes in improving the nutritional value of OPF and was more cost-effective, safe, and environmental-friendly compared to chemical and physical treatments. In vitro rumen fermentation studies on the potential use of treated OPF as feedstuffs for ruminants have been widely reported. Several in vivo studies have found that ruminants performed satisfactorily when fed diets with treated OPF at appropriate ratios. Nevertheless, chemically treated OPF has been successfully used in both beef and dairy cattle feeding trials as it is a good source of protein and has positive impacts on ruminal fermentation and animal production.
\end{abstract}

Keywords: feed, in vitro rumen fermentation, oil palm frond, ruminants, treatment.

Received: 12 May 2021; Accepted: 28 July 2021; Published online: 14 October 2021.

\section{INTRODUCTION}

Profitable and sustainable livestock productivity in tropical regions is often limited by the high cost of conventional feed resources and competition from human nutrition. Hence, bioconversion of

Malaysian Palm Oil Board,

6 Persiaran Institusi, Bandar Baru Bangi,

43000 Kajang, Selangor, Malaysia.

2 Institute of Tropical Agriculture and Food Security, Universiti Putra Malaysia,

43400 Serdang, Selangor, Malaysia.

3 Department of Animal Science,

Faculty of Agriculture, Universiti Putra Malaysia, 43400 Serdang, Selangor, Malaysia.

* Corresponding author e-mail: saminathan@mpob.gov.my agro-industrial waste or by-products has become an alternative for the economic and sustainable production of feed for both ruminants and nonruminants. The oil palm (Elaeis guineensis Jacq.) industry in Malaysia produces large quantities of biomass residues annually that can potentially be used as indigenous feed ingredients for livestock feeding, such as oil palm frond (OPF), oil palm trunk (OPT), palm press fibre (PPF), empty fruit bunches (EFBs), palm kernel cake (PKC), palm oil mill effluent (POME) and decanter cake (Soh et al., 2018). Oil palm biomass residues have become increasingly explored and exploited as promising alternatives to conventional feed for their ability to overcome the problem of feed resource waste, promote the sustainability of oil palm cultivation, and does not harm the environment (Kushairi et al., 2019). Current trends in feed science and 
technology in animal nutrition may provide appropriate means for effectively utilising locally available crop residues in appreciable quantities to maximise the benefits of feed in animal systems.

OPF consists of leaves and petioles of oil palms and is a major cellulosic solid crop residue utilised as a fibre-forage complete feed for ruminants (Kum and Zahari, 2011). OPF is generally obtained during pruning operations in plantations. The availability of OPF in 2020 was estimated to be approximately 49.0 million tonnes (dry weight basis) and is likely to increase in the future (Agensi Inovasi Malaysia, 2013). OPF can be utilised as a ruminant feed either as chopped green or fermented silage in combination with concentrate as a complete feed or total mixed rations (TMRs). Incorporating OPF into the ruminant diet might provide an effective way of overcoming the typical limitations of pastures for sustaining animal production in palm oilproducing countries, including Malaysia. Balanced and economical feeding of fibrous crop residues is fundamental for optimising the voluntary intake of feed, enhancing its utilisation, and improving animal husbandry (Beigh et al., 2017).

The widespread use of OPF as ruminant feed suggests that it is important for meeting the net energy needs and nutritional requirements of animals. However, the inherent limitations of OPF as a feed include its complex biological structure, high lignocellulosic content, low nutritional value, and low energy content, which often fail to meet the nutritional requirements of ruminants (Rahman et al., 2011). Furthermore, the abundance of lignin $\left(\sim 199 \mathrm{~g} \mathrm{~kg}^{-1}\right.$ dry matter, DM) in OPF reduces the accessibility and use of structural carbohydrates for rumen microbial fermentation (Ishida and Abu Hassan, 1997). In such circumstances, feeding ruminants with low-quality OPF can result in rumen dysfunction, nutritional inadequacy and poor growth performance. Hence, efforts are being made to develop effective treatment methods for OPF to enhance its nutritional quality as feedstuff needed for new fodders feeding strategies and prevent the scarcity of balanced feeds (Rusli et al., 2019). The improvement of the nutritional value of OPF is one of the latest developments in oil palm waste management for exploiting the potential of locally available feedstuffs and optimising its utilisation as an animal feed resource (Wu et al., 2020).

Many studies on the conversion of OPF to valuable feedstuffs via biological, chemical and physical methods have been conducted to elucidate how animals could utilise this lower-grade feedstuff more effectively. An abundance of information on the nutritional value, biochemical properties, treatment methods and feeding response of treated OPF as a ruminant feedstuff are also available. Thus, this article is aimed to investigate the ability of various treatments in maximising the nutritional value of OPF as an improved feedstuff for ruminants through in vitro and in vivo studies. Specifically, the effects of different treatment methods of OPF to maximise digestibility coefficients, rumen fermentation, ruminant production performance, milk production and compositional traits of both cattle and goats will also be reviewed. Improving the feed value of OPF is becoming increasingly important as it permits the increased use of oil palm crop residues in ruminant diets while minimising feed costs and maximising feed production.

\section{CHEMICAL COMPOSITION OF OPF}

Much research has been conducted on the potential utility of OPF as an animal feed ingredient, including comprehensive proximate chemical studies. The chemical composition of OPF can be determined by the feed analysis method based on the neutral detergent system (Ishida and Abu Hassan, 1997). Nevertheless, the chemical properties of OPF biomass may vary depending on plant nutrient uptake, which is influenced by several factors, such as the age of OPF collected, geographical conditions, types of fertilisers applied, and soil chemistry (Ooi et al., 2017). Table 1 shows the typical proximate chemical composition and metabolisable energy (ME) of OPF adopted from Ishida and Abu Hassan (1992), Hong et al. (2012) and Mathius (2008). The nutritional analysis showed that OPF is composed of $22 \%$ soluble carbohydrates and $70 \%$ fibre on a dry matter (DM) basis. Therefore, OPF has a low

TABLE 1. PROXIMATE CHEMICAL COMPOSITION AND METABOLISABLE ENERGY (ME) OF OIL PALM FROND (OPF)

\begin{tabular}{lc}
\hline Parameters & Composition (\%) \\
\hline Dry matter (DM) & $31.10-48.78$ \\
Percentage in DM & \\
Crude protein (CP) & $4.21-5.33$ \\
Ether extract (EE) & $2.00-3.14$ \\
Crude fibre (CF) & $48.25-50.20$ \\
Crude ash & $4.48-4.75$ \\
Nitrogen free extract (NFE) & $36.45-38.3$ \\
Neutral detergent fibre (NDF) & $69.50-78.05$ \\
Acid detergent fibre (ADF) & $50.9-56.93$ \\
Hemicellulose & $11.91-21.12$ \\
Cellulose & $27.94-39.63$ \\
Lignin & $16.94-20.50$ \\
ME (MJ kg-1 DM) & $4.90-5.60$ \\
\hline
\end{tabular}

Note: Adopted from Ishida and Abu Hassan (1992), Mathius (2008) and Hong et al. (2012). 
ME value, ranging between 4.9 $\mathrm{MJ} \mathrm{kg}^{-1}$ and 5.6 MJ $\mathrm{kg}^{-1}$ DM. Naturally, OPF has quantities of nutrients (\% DM) similar to those in typical pastures used for grazing. The high levels of crude fibre $(\mathrm{CF}, 48.25 \%$ $50.20 \%$ of DM) make OPF a very promising source of feed for ruminants. Indeed, OPF consists of non-edible lignocellulosic plant materials (lignin, cellulose and hemicellulose), of which the fibrous elements of the cell wall make OPF less digestible for ruminants (Zakaria et al., 2014).

In addition, OPF contains a minimum amount of plant secondary metabolites compounds (polyphenol compounds) such as tannins, flavonoids, saponins and catechins (Aiman-Zakaria et al., 2017). Among these, tannins (both condensed and hydrolysable tannins) which represent the most abundant group of polyphenol compounds in OPF (30.9 $\left.\mathrm{g} \mathrm{kg}^{-1}\right)$, have been reported to help avoid biohydrogenation of fatty acids, improve rumen metabolism and mitigate methane production in ruminants (Jenkins et al., 2008; Patra and Saxena, 2011). The smallest amount of amino acids, organic acids, minerals and vitamins are also present in the OPF (Ishida and Abu Hassan, 1997). OPF also contains a reasonable number of inorganic elements such as potassium $\left(7 \mathrm{~g} \mathrm{~kg}^{-1}\right)$ and calcium $\left(5.3 \mathrm{~g} \mathrm{~kg}^{-1}\right)$ which are essential to animal nutrition, metabolism, and growth performance (Ishida and Abu Hassan, 1997).

\section{USE OF OPF AS A RUMINANT FEEDSTUFF}

Research had shown that OPF could be used successfully as a viable ruminant forage feed. Moreover, fresh OPF has been extensively processed as pelleted feed for trade and export. Toxicity problems and adverse health effects have not been reported for OPF ruminant feeding (Ishida and Abu Hassan, 1992), and the product seems readily accepted and palatable for goat, sheep, dairy goat, beef cattle, and dairy cattle (Ooi et al., 2017). Thus, OPF has been used as a source of roughage to replace rice straw and other low-quality roughage commonly used in ruminant feeding without detrimental effects on livestock production.

The use of OPF as a feedstuff for small ruminants and its effect on fibre digestion and nutrient intake has been widely discussed (Dahlan, 2000; Dahlan et al., 1993; Ebrahimi et al., 2014; Rajion et al., 2001). Dahlan et al. (1993) found that the typical metabolisable energy intake (MEI) of goats fed a diet of pure OPF was $311.3 \mathrm{ME} \mathrm{kg}^{-1}$ body weight ${ }^{0.75}$ $\left(\mathrm{BW}^{0.75}\right)$, which is within the range (230.5 to 580.8 $\mathrm{ME} \mathrm{kg}{ }^{-1} \mathrm{BW}^{0.75}$ ) of the optimal energy maintenance requirements for goats. Besides meeting the energy requirements for small ruminants, several of the beneficial effects of using OPF have been achieved through its use as a feed. For example, Meng et al.
(2018) suggested that sheep diets composed of 50\% OPF have beneficial effects on blood plasma lipid parameters and fatty acid (FA) profiles in rumen fluid and muscle tissues.

Moreover, OPF could be used as a replacement for native grasses when the availability of forage or fodder for beef and dairy cow feed becomes limiting. The recommended amount of OPF included in TMRs (on a DM basis) is 30\% for dairy cattle and 50\% for beef cattle. The nutritional needs of dairy cattle after calving are closely related to the live weight of animals and to the level of milk production, while feed intake is associated with the composite of rough fibre in feed. Advantages of OPF feeding include solving roughage/feed shortages, improving milk quality in dairy farms, and reducing feeding, operational and management costs (Dahlan et al., 1993).

\section{LIMITATIONS OF OPF AS A RUMINANT FEEDSTUFF}

The effective application of OPF as whole feedstuff for animal production is limited by its large quantities of cellulolytic materials, poor nutrient digestibility coefficients, low ME values, resistance to enzymatic hydrolysis, low palatability and possession of some anti-nutritional factors such as high lignin content, non-starch polysaccharides, tannin and phenolic compounds (Febrina et al., 2014). OPF contains substantial quantities of lignin, which is a large complex structure that adheres to the matrix of hemicellulose and cellulose of the cell wall to form crystalline structures called microfibrils or lignocellulose biopolymers. Plant lignin confers rigidity and impermeability to the cell wall, facilitating resistance to microbial attack and oxidative stress (Rizal et al., 2018). The large biomass of lignocelluloses and low ligninolytic activity of rumen microbes reduce the digestibility of fibre in the rumen and restrict the efficient use of lignocelluloses as feedstuff in ruminants.

Moreover, OPF contains low levels of protein $(4.0 \%-7.5 \%)$ unless processed (Ooi et al., 2017). The insufficient protein content in OPF could lower the digestibility coefficient and decrease the absorption of nutrients needed to support the optimal productivity of ruminants. Furthermore, unprocessed OPF, which contains $>50 \%$ moisture, tends to deteriorate and develop mould, reducing its palatability and decreasing the DM nutrient intake, weight gain, and milk production of ruminants (Dahlan, 2000). In addition, mouldy OPF may have an undesirable taste and texture, a low nutritional value, and may become heavily contaminated with fungal mycotoxins. Likewise, oil palm leaves are rich in secondary metabolite substances, such as tannins and phenolic compounds, which might be 
detrimental to ruminant fermentation, microbial populations, the DM digestibility of feed, growth performance, and milk production (Ebrahimi et al., 2015; Jaffri et al., 2011). Saminathan et al. (2016; 2019) revealed that the secondary metabolites and bioactive compounds from plants, particularly hydrolysable and condensed tannins at a concentration of 20-30 $\mathrm{g} \mathrm{kg}^{-1}$ could be harmful to the fibrolytic anaerobic rumen bacteria such as Fibrobacter succinogenes and Ruminococcus spp., and anaerobic fungi species such as monocentric Neocallimastix spp., and Piromyces spp., in the rumen.

\section{TREATMENT OF OPF}

The structural arrangement of OPF elements and their chemical composition plays a significant role in dictating its utility as a feedstuff. Treatment of OPF to create value-added feedstuffs is an important step for enhancing the nutritional value of this material for ruminant feeding. Possible treatment is needed to alter the fibrous structure of OPF at both the macro- and microscopic scales to facilitate more efficient and rapid digestion and increased accessibility for the rumen microbiota (Hermiati et al., 2013; Rizal et al., 2018; Rusli et al., 2019). OPF can be treated by biological, physical and chemical means, or their combinations as shown in Figure 1, whereby each treatment method has advantages and disadvantages (Table 2). OPF treatments mainly involve delignifying processes that increase the cellulose content and effectively improve the availability of other nutrition for ruminants in a costeffective and sustainable way (Galbe and Zacchi, 2012; Rizal et al., 2018).

\section{PHYSICAL AND PHYSICO-CHEMICAL TREATMENT METHODS}

Several common physical treatment methods have been developed to enhance the value of OPF as a feed, which include pelleting, grinding, chopping and steaming. Grinding, pelleting and steaming process increased the digestibility of OPF hence, improved the feed intake and growth performance of ruminants (Wan Zahari et al., 2003). Physico-chemical treatment comprises both physical and chemical interactions in the treatment of OPF. All the physicochemical treatments of fibrous substances are carried out at extremely high pressure and temperature in a closed system (Rabemanolontsoa and Saka, 2016). Steam explosion, ammonia $\left(\mathrm{NH}_{3}\right)$ fibre explosion and fibre cracking technology (FCT) are among the most recently used methods to partially hydrolyse the glycosidic bonds of hemicellulose, decrease cellulose crystallinity, disrupt chemical bonding and increase the surface area of OPF lignocellulosic substances (Jayanegara et al., 2019). The large surface area of OPF could increase the attachment of rumen microbes and the accessibility of enzymes, thereby increasing the biodegradability of plant cell walls and fibre fermentation. Wu et al. (2020)

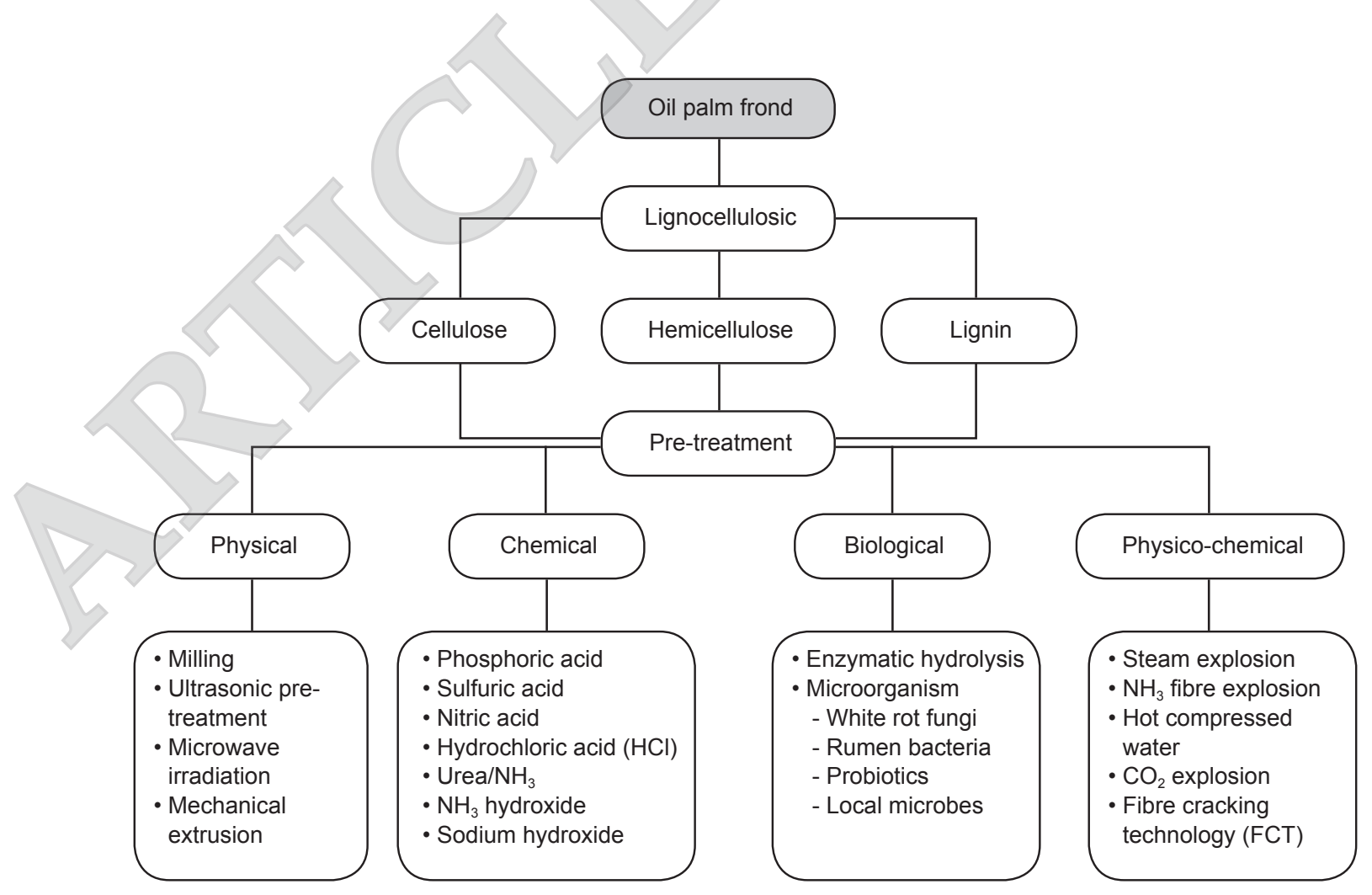

Figure 1. Different types of oil palm frond (OPF) pre-treatment methods. 
TABLE 2. ADVANTAGES AND DISADVANTAGES OF PHYSICAL, PHYSICO-CHEMICAL, CHEMICAL AND BIOLOGICAL TREATMENT METHODS OF OIL PALM FROND (OPF)

\begin{tabular}{|c|c|c|c|c|}
\hline Treatment category & Treatment methods & Advantages & Disadvantages & References \\
\hline Physical & $\begin{array}{l}\text { Pelleting/grinding/ } \\
\text { chopping/steaming }\end{array}$ & $\begin{array}{l}\text { Short process duration; } \\
\text { efficiently reduces the } \\
\text { substrate size; increases the } \\
\text { surface area of biomass }\end{array}$ & $\begin{array}{l}\text { High cost for equipment and } \\
\text { machinery setup; required } \\
\text { additional treatment as it does } \\
\text { not remove lignin }\end{array}$ & $\begin{array}{l}\text { Galbe and Zacchi } \\
\text { (2012) }\end{array}$ \\
\hline Physico-chemical & $\begin{array}{l}\text { Steam explosion/ } \\
\text { fibre cracking } \\
\text { technology (FCT)/ } \\
\text { hot water }\end{array}$ & $\begin{array}{l}\text { No chemicals used; } \\
\text { adequate for large-scale } \\
\text { application; environment- } \\
\text { friendly; low energy input }\end{array}$ & $\begin{array}{l}\text { Risk of condensation and } \\
\text { precipitation of soluble lignin } \\
\text { components; not effective in } \\
\text { removing lignin; incomplete } \\
\text { destruction of the lignin- } \\
\text { carbohydrate matrix }\end{array}$ & $\begin{array}{l}\text { Wan Zahari } \\
\text { et al. (2003) } \\
\text { Rabemanolontsoa and } \\
\text { Saka (2016) }\end{array}$ \\
\hline Chemical & $\begin{array}{l}\text { Acid/alkali/ionic } \\
\text { liquids/urea }\end{array}$ & $\begin{array}{l}\text { Short process duration; } \\
\text { selectively attacks the } \\
\text { lignin; possible to fully } \\
\text { hydrolyse the entire lignin }\end{array}$ & $\begin{array}{l}\text { Toxic to enzymes and } \\
\text { fermentation; not economically } \\
\text { feasible; less effective if the } \\
\text { lignin content is high in } \\
\text { biomass; usually requires high } \\
\text { temperature to dissolve lignin }\end{array}$ & $\begin{array}{l}\text { Mosier et al. (2005) } \\
\text { Kristiani et al. (2013) } \\
\text { Noparat et al. (2015) }\end{array}$ \\
\hline Biological & $\begin{array}{l}\text { Fungi/bacteria/ } \\
\text { ligninolytic } \\
\text { enzymes/fibrolytic } \\
\text { enzymes }\end{array}$ & $\begin{array}{l}\text { Selectively degrades lignin; } \\
\text { environment-friendly; } \\
\text { requires mild operating } \\
\text { conditions }\end{array}$ & $\begin{array}{l}\text { Slow process and therefore it } \\
\text { needs long process duration; } \\
\text { requires large space; enzyme cost } \\
\text { is very high; some carbohydrate } \\
\text { fraction is consumed by the } \\
\text { microorganism }\end{array}$ & $\begin{array}{l}\text { Hassim et al. (2012) } \\
\text { Yunilas et al. (2014) } \\
\text { Barlianti et al. (2015) }\end{array}$ \\
\hline
\end{tabular}

showed that steam explosion could effectively improve the ME value of OPF and decrease the hemicellulose content of OPF from $22.81 \%$ to $18.80 \%$. For instance, steam explosion treatment is an important method for aiding the release of OPF cellulose implanted between hemicelluloses and lignin and is more applicable to rumen fermentation, hydrolysis and densification processes. Moreover, higher yields of OPF hemicelluloses containing various monosaccharide subunits can be obtained from steam explosion technology relative to other treatment methods (Garrote et al., 1999). Harahap et al. (2018) reported that the acid detergent fibre $(\mathrm{ADF})$ and neutral detergent fibre (NDF) content of OPF decreased after the FCT treatment process, thereby increasing the hydrolysis of complex carbohydrates. In addition, microwave irradiation could enhance the rupture of the rigid structure of lignin biomass and eventually increase the susceptibility of lignocellulosic substances (Binod et al., 2012; Zhang and Zhao, 2010).

\section{CHEMICAL TREATMENT METHOD}

Chemical treatment with diluted acid or alkaline solutions is one of the most common methods that has been used to treat fresh or dried OPF. Chemical treatment requires the maintenance of low temperature and pressure compared to other treatment strategies (Mosier et al., 2005). Acid treatment involves hydrolysis of hemicellulose components of OPF and the release of cellulose components for conversion into fermentable carbohydrates by rumen microbes. Application of diluted acid is among the major concerns requiring consideration in the chemical treatment of lignocellulosic substances to avoid overexposure of OPF to harsh conditions. To date, diluted acids that have been used for OPF treatment include phosphoric acid $\left(\mathrm{H}_{3} \mathrm{PO}_{4}\right)$, sulphuric acid $\left(\mathrm{H}_{2} \mathrm{SO}_{4}\right)$, nitric acid $\left(\mathrm{HNO}_{3}\right)$, and hydrochloric acid $(\mathrm{HCl})$ (Awalludin et al., 2015; Kristiani et al., 2013; Noparat et al., 2015). Kristiani et al. (2013) discovered that treatment of OPF with diluted acid could alter the surface structure and concurrently increase specific surface area, thereby reducing the crystallinity of cellulose matter in OPF. However, the utilisation of acid is less applicable for OPF treatment because of the formation of inhibitors that might inhibit the enzymatic activity of microbes during rumen fermentation. Likewise, high operational and maintenance costs are major limitations of this method that preclude the application of this technique on a commercial scale.

Diluted alkaline hydrolysis is perhaps the most common method used to treat OPF. Alkaline treatment might trigger the swelling of lignocellulosic materials of plants and the disintegration of hemicellulose and lignin. Inclusion of non-protein nitrogen (NPN) resources, such as $\mathrm{NH}_{3}$ or urea $\mathrm{N}$ and ammonium hydroxide 
$\left(\mathrm{NH}_{4} \mathrm{OH}\right)$, is the method typically applied for poorquality OPF given the ease with which they can be managed at low costs. Supplementation of OPF with NPN such as urea has been shown to improve the nutritional value and nutrient digestibility of OPF and, in turn, the ease with which the energy and protein requirements of ruminants can be met. Urea can break down plant lignocellulose materials and enhance the nitrogen $(\mathrm{N})$ level available for microbial protein synthesis in the rumen (Gunun et al., 2016). However, several factors require consideration for the urea treatment to be successful, including the concentration of urea, moisture content and duration of pre-treatment (Rusli et al., 2019). Treating OPF silage with urea could prevent mould growth under aerobic conditions and concomitantly increase the level of organic acids (acetic and butyric acids) that animals might absorb as a major energy source. Generally, alkaline treatments are preferable to acid treatments, given that alkaline solutions delignify the lignin of OPF more effectively than acids. Barlianti et al. (2015) discovered that alkaline treatment improved the availability of carbohydrates up to $6 \mathrm{~g} \mathrm{litre}^{-1}$ after pre-treatment of OPF with $1 \%$ of $\mathrm{NaOH}$.

\section{BIOLOGICAL TREATMENT METHOD}

In recent decades, the biological treatment method, which is known for providing an environmentalfriendly approach, has received considerable attention to enhance the nutritional properties and ruminal feeding value of OPF. Biological treatment of biomass generally involves two key methods: enzymatic and microorganism treatments. These biological methods are becoming famous, particularly in developing countries, due to the recent developments in fermentation technology to produce large quantities of fungi or their enzymes to meet the requirements, and the costs of these materials are expected to decline in the future (Rizal et al., 2018).
The typical microorganisms used for OPF treatment include white fungi, rumen bacteria, and local microbes (Azmi et al., 2019; Hassim et al., 2012; Rahman et al., 2011; Yunilas et al., 2014). The number of bacterial strains which show lignindegrading ability are quite limited. However, there are several fibre-degrading bacteria species (Actinomycetes, Nocardia, Streptomyces, and Eubacteria) which are identified by their role in the hydrolysis of fibre content in biomass to some extent (Azmi et al., 2019). Similar to chemical treatments, the microorganism's treatment method applied on OPF results in the breakdown of lignocellulosic fibres in OPF and thus, enhances the in vitro degradability of cellulose by up to $31 \%$ in the rumen (Rahman et al., 2011). However, bacterial strains to treat OPF are no longer popular due to their slower reaction response, compared to that obtained with fungi. White-rot fungi (WRF) are extensively used in OPF treatment to efficiently break down plant lignin and cell walls. Indigenous probiotics derived from palm oil waste, which include Bacillus sp. YLB1, Saccharomyces sp. YLY3 and Trichoderma sp. YLF8, all have the capability of biodegrading OPF fibres and increasing crude protein $(\mathrm{CP})$ content through the microbial fermentation process (Yunilas et al., 2014). The proximate chemical analysis of OPF treated with WRF, rumen microorganisms and probiotics is shown in Table 3.

Numerous studies have shown that fungal degradation of OPF lignin via biological delignification using WRF could improve the chemical composition of OPF and may be of significant value to ruminant feedstuff and feeding (Chanjula et al., 2015; 2018; Hamchara et al., 2018; Rahman et al., 2011). The effectiveness of WRF enzyme activity might be influenced by the type of fungal species or strain used. WRF, effective wooddecaying basidiomycetes in nature, actively secrete lignin-modifying enzymes (LMEs), specifically laccase (Lac), manganese peroxidase $(\mathrm{MnP})$ and lignin peroxidase (LiP), which have high ligninolytic activity (Namoolnoy et al., 2011). Among the edible

TABLE 3. PROXIMATE ANALYSIS OF TREATED OIL PALM FROND (OPF) WITH WHITE ROT FUNGI, RUMEN MICROORGANISMS AND PROBIOTICS

\begin{tabular}{|c|c|c|c|c|c|c|c|}
\hline Type of microorganism & $\begin{array}{l}\mathrm{DM} \\
(\%)\end{array}$ & $\begin{array}{l}\mathrm{CP} \\
(\%)\end{array}$ & $\begin{array}{c}\mathrm{EE} \\
(\%)\end{array}$ & $\begin{array}{l}\mathrm{CF} \\
(\%)\end{array}$ & $\begin{array}{l}\text { Ash } \\
(\%)\end{array}$ & $\begin{array}{c}\mathrm{ME} \\
\left(\mathrm{MJ} \mathrm{kg}^{-1}\right)\end{array}$ & References \\
\hline Lactobacillus plantarum MTD1 & ND & 4.78 & 2.85 & 38.50 & 7.53 & ND & Ebrahimi et al. (2015) \\
\hline $\begin{array}{l}\text { Prolinas } \\
\text { (Pineapple skin probiotic) }\end{array}$ & 83.57 & 6.58 & 2.18 & 32.70 & 6.99 & ND & Mardalena et al. (2019) \\
\hline $\begin{array}{l}\text { Produren } \\
\text { (a durian probiotic) }\end{array}$ & 92.34 & 15.34 & 2.21 & 33.31 & 5.92 & ND & $\begin{array}{l}\text { Mardalena and } \\
\text { Musnandar (2019) }\end{array}$ \\
\hline Fungal strain (Lentinus sajor-caju spp.) & 50.83 & 7.24 & 1.87 & 36.49 & 7.40 & ND & Chanjula et al. (2017) \\
\hline Lentinus sajor-caju spp. & 39.47 & 6.18 & 1.82 & 28.38 & 8.29 & 4.33 & Hamchara et al. (2018) \\
\hline
\end{tabular}

Note: CF - crude fibre; CP - crude protein; DM - dry matter; EE - ether extract; ME - metabolisable energy; ND - not determined. 
WRF, Schizophyllum sp. and Lentinus sajor-caju are more active in breaking down lignocellulosic materials than other WRF species. Lentinus sajor-caju can only consume the lignin and hemicellulose of $\mathrm{OPF}$, leaving the cellulose in perfect condition so that it can contribute to improving the supply of energy for ruminants. Additionally, fungi-treated OPF is an excellent source of amino acids, peptides and small proteins. Previous research has also shown that the mechanism of DM loss in OPF and the fermentation profile triggered by WRF are correlated to the selective disappearance of lignin (Hassim et al., 2012). On the other hand, Azmi et al. (2019) isolated specific fungi from rotten OPF (non-WRF species); namely, Fusarium solani and T. harzianum strains, and demonstrated the optimum activity of the enzyme as a biological treatment agent for improving the use of OPF as a ruminant feedstuff.

Fibrolytic enzymes that catalyse hydrolysis play a vital role in animal feeding by enhancing the digestibility of feed and the conversion of feedstuff into added-value end-products (Sujani and Seresinhe, 2015). Enhancement of the nutritional value of OPF through the treatment of exogenous fibrolytic enzymes has been the subject of much research. Hemicellulose and cellulose can be digested enzymatically into glucose and other metabolisable sugar components, such as hexose and pentose, which can be absorbed by the bloodstream of animals as energy sources. The mixture of enzymes exhibiting fibrolytic activities (e.g., hemicelluloses, cellulases, mannanases and xylanase) can be potentially used to enhance the degradability of low-quality fibrous substrates in OPF (Hassim et al., 2012). OPF treated with Hemicell ${ }^{\circledR}$ containing mostly $\beta$-D-mannanase that degrade mannan might increase the rate of rumen fermentation due to the ease of access that several ruminal cellulolytic bacteria species have to nonstarch polysaccharides (NSPs) from OPF (Wahyuni, 2012). On the other hand, the inclusion of tannase in OPF feed can hydrolyse anti-nutritional phenolic substrates in the OPF, which might decrease feed intake and adversely affect rumen DM digestion (Abd El Tawab et al., 2015; Curiel et al., 2009). Abd El Tawab et al. (2015) reported that the supplementation of tannase as a feed additive for lactating goats could reduce the hydrolysable and condensed tannin contents in plant-based feed and enhance milk production and the rumen fermentation profile. The inclusion of fibre-degrading enzymes into fermented OPF with WRF should be more effective and exhibit synergistic effects relative to the outcome of OPF inoculation with WRF alone. However, Hassim et al. (2012) showed that the inclusion of both OPF treated with WRF and fibrolytic enzymes did not increase the in vitro digestibility of OPF, suggesting that no synergism occurs between treated OPF and enzymes. This finding indicates that there is a need to further optimise enzyme combinations depending on the type of plant carbohydrates in the substrate.

A summary of different treatments (physical, physico-chemical, chemical, and biological treatment) effects on chemical composition and physical and biological properties of OPF is shown in Table 4.

\section{EFFECTS OF TREATED OPF ON IN VITRO RUMEN FERMENTATION CHARACTERISTICS}

A novel approach known as the in vitro rumen fermentation technique, and specifically the in vitro gas production technique, could provide an effective method for assessing the nutritional value of ruminant feeds. The chemical or proximate analysis of feedstuffs only suggests the nutritional value and composition but does not provide information about the actual ruminal fermentable and digestible values of feedstuff. Several studies of in vitro gas production techniques and rumen fermentation of treated OPF have been performed to predict its digestibility and potential use as a quality feedstuff for ruminants (Boonthep et al., 2011; Hassim et al., 2012; Mulianda et al., 2018; Tafsin et al., 2018).

Many beneficial effects of incorporating treated OPF feedstuffs into complete feeds during in vitro rumen fermentation have been documented. For example, Boonthep et al. (2011) showed that predigestion of OPF by Aspergillus spp. BCC274 could significantly increase in vitro gas production and OPF digestibility. Several studies have found that OPF when biologically treated with WRF, or an enzyme extract of WRF, shows promise for enhancing in vitro DM degradability (IVDMD) and in vitro organic matter degradability (IVOMD) by breaking down the lignocellulosic biomass in OPF fibres (Febrina et al., 2016; Rahman et al., 2011; Rusli et al., 2019). WRF are the most effective microbes for delignification due to their production of fibrolytic enzymes and/ or ligninolytic extracellular oxidative enzymes, which can improve the digestibility of DM of poorquality forages, such as OPF. Nevertheless, the solidstate fermentation period, fungal strain, substrate, and culture conditions are key factors determining the digestibility coefficient of pre-digested OPF. Digestibility coefficient is a benchmark for early determination of the availability of the total quantity of nutrients in feedstuff consumed by livestock. The high digestibility coefficient of DM in treated OPF based on in vitro analysis reflects the significant contribution of specific nutrients to ruminants.

Rahman et al. (2011) carried out an in vitro study by screening 10 different WRF for their ability to convert plant lignin to carbohydrates and their effects on the in vitro ruminal degradability of OPF. Among the WRF tested, OPF inoculated with $L$. edodes and P. brevispora for nine weeks and 
TABLE 4. DIFFERENT TREATMENT EFFECTS ON CHEMICAL COMPOSITION AND PHYSICAL AND BIOLOGICAL PROPERTIES OF OIL PALM FROND (OPF)

\begin{tabular}{|c|c|c|c|}
\hline Treatment type & Treatment methods & Chemical composition and physical and biological properties & References \\
\hline Physical & $\begin{array}{l}\text { Pelleting, grinding } \\
\text { and chopping }\end{array}$ & $\downarrow$ particle size; $\uparrow$ OPF surface area; $\uparrow$ digestibility and feed intake & $\begin{array}{l}\text { Wan Zahari et al. } \\
\text { (2003) }\end{array}$ \\
\hline \multirow[t]{2}{*}{ Physico-chemical } & Steam explosion & $\begin{array}{l}\downarrow \text { NDF and ADF; improve energy value; } \\
\downarrow \text { hemicellulose content of OPF from } 22.8 \% \text { to } 18.8 \%\end{array}$ & Wu et al. (2020) \\
\hline & $\begin{array}{l}\text { Fibre cracking } \\
\text { technology (FCT) }\end{array}$ & $\begin{array}{l}\text { Disrupt chemical bonding; } \downarrow \text { NDF and ADF by } 29.8 \% \text { and } \\
14.2 \% \text {, respectively }\end{array}$ & $\begin{array}{l}\text { Harahap et al. } \\
\text { (2018) }\end{array}$ \\
\hline \multirow[t]{3}{*}{ Chemical } & Urea & $\begin{array}{l}\text { Break down OPF lignocellulose materials; } \uparrow \mathrm{N} \text { availability; } \\
\uparrow \text { the level of an organic acid; } \uparrow \mathrm{CP} \text { content }(10 \%-25 \%)\end{array}$ & Wu et al. (2020) \\
\hline & Diluted acid & $\begin{array}{l}\uparrow \text { specific surface area of OPF from } 2.23 \mathrm{~m}^{2} \mathrm{~g}^{-1} \text { to } 5.57 \mathrm{~m}^{2} \mathrm{~g} \\
\downarrow \text { crystallinity of cellulose molecule }\end{array}$ & $\begin{array}{l}\text { Kristiani et al. } \\
(2013)\end{array}$ \\
\hline & Alkali treatment & $\begin{array}{l}\text { Delignify the lignin of OPF, } \downarrow \text { lignin content from } 30.9 \% \\
\text { to } 19.2 \% \text {; lower cellulose crystallinity index; improve the } \\
\text { availability of carbohydrates up to } 6 \mathrm{~g} \text { litre }^{-1}\end{array}$ & $\begin{array}{l}\text { Barlianti et al. } \\
\text { (2015) }\end{array}$ \\
\hline \multirow[t]{6}{*}{ Biological } & $\begin{array}{l}\text { White-rot fungi (WRF) } \\
\text { (Lentinus sajor-caju) }\end{array}$ & $\begin{array}{l}\text { Efficiently break down OPF lignin and cell walls; optimum } \\
\text { enzyme activity; } \uparrow \text { in vitro rumen degradability of } \\
\text { carbohydrates by up to } 31 \%\end{array}$ & $\begin{array}{l}\text { Rahman et al. } \\
\text { (2011) }\end{array}$ \\
\hline & $\begin{array}{l}\text { White-rot fungi (WRF) } \\
\text { (Schizophyllum spp. and } \\
\text { Lentinus sajor-caju) }\end{array}$ & $\begin{array}{l}\text { Actively secrete lignin-modifying enzymes; } \\
\text { excellent source of amino acids }\end{array}$ & $\begin{array}{l}\text { Namoolnoy et al. } \\
\text { (2011) }\end{array}$ \\
\hline & $\begin{array}{l}\text { Non-white-rot fungi } \\
\text { (Fusarium solani and } \\
\text { T. harzianum) }\end{array}$ & $\begin{array}{l}\downarrow \text { OPF lignin from } 30 \% \text { to } 15 \% \text {; highest laccase and manganese } \\
\text { peroxidase }(\mathrm{MnP}) \text { activities }\left(0.89 \mathrm{U} \mathrm{g}^{-1} \text { and } 0.79 \mathrm{U} \mathrm{g}^{-1} \text { of DW, }\right. \\
\text { respectively) } \\
\text { Produces high lignolytic enzymes }\end{array}$ & Azmi et al. (2019) \\
\hline & $\begin{array}{l}\text { Probiotic (Bacillus spp. } \\
\text { and Saccharomyces spp.) }\end{array}$ & Improve biodegradation of OPF fibres; $\uparrow \mathrm{CP}$ content & $\begin{array}{l}\text { Yunilas et al. } \\
(2014)\end{array}$ \\
\hline & Fibrolytic enzymes & $\begin{array}{l}\text { Degradability of low-quality fibrous substrate in OPF; } \\
\beta \text {-D-mannanase degrade mannan and } \uparrow \text { rate of fermentation }\end{array}$ & $\begin{array}{l}\text { Hassim et al. } \\
(2012)\end{array}$ \\
\hline & Tannase enzymes & $\begin{array}{l}\text { Degrade non-nutritional component (secondary metabolite } \\
\text { compounds) in OPF }\end{array}$ & $\begin{array}{l}\text { Abd El Tawab } \\
\text { et al. (2015) }\end{array}$ \\
\hline
\end{tabular}

Note: ADF - acid detergent fibre; CP - crude protein; DW - dry weight; NDF - neutral detergent fibre; OPF - oil palm frond; $\uparrow$ - increase; $\downarrow$ - decrease.

C. subvermispora for three weeks showed higher degrees of lignin loss, which were positively correlated with an increase in in vitro gas production and volatile fatty acid (VFA) concentrations. Suggested mechanisms for improving OPF nutrient content include the degradation of lignin to lignocellulose and the partial degradation of biological cellulose, which improved the accessibility of the substrate to rumen microorganisms. Furthermore, a decrease in fibre fractions in treated biomass via WRF treatment could increase the in vitro digestibility of bovine rumen fluid and the quantity of product palatable to cattle (Okano et al., 2006). In another experiment, Hassim et al. (2012) concluded that the inclusion of L. edodes and C. subvermispora inoculum in OPF could improve the apparent rumen degradable carbohydrate (ARDC) and / or in vitro gas production rates; however, additional exogenous enzyme supplementation did not further improve
ARDC activity. Inclusion of the ideal combination of minerals (150 ppm Ca and 2000 ppm Mn) during OPF fermentation by $P$. chrysosporium significantly enhanced $(p<0.05)$ the in vitro digestibility of DM, organic matter, NDF, and cellulose and consequently increased the concentration of VFA (Febrina et al., 2016). The addition of minerals capable of increasing the quantity of fungal mycelium and the production of ligninolytic enzymes can promote the cleavage of bonds within lignocellulose and lignohemicellulose. Moreover, the lignin degradation activity of fungi is influenced by $\mathrm{MnP}$, a non-specific extracellular enzyme system, and the stability and activity of $\mathrm{MnP}$ are dependent on the concentration of $\mathrm{Mn}^{2+}$ (Pazarlioglu et al., 2005).

The application of local microorganisms in OPF bio-fermentation and their effects on ruminant digestion efficiency and feed fermentability has been evaluated in vitro to measure the nutritional quality 
of livestock feed. A stable microbial ecological condition within the rumen is one of the factors that can increase the consumption rate, thereby giving the ruminants more nutrients and energy. Likewise, Tafsin et al. (2018) showed that fermenting OPF with local microorganisms (A. niger and $S$. cerevisiae) and isolates of buffalo rumen bacteria improved the digestibility of DM and organic matter in vitro. Mulianda et al. (2018) found that application of local microorganisms at the level of $0.6 \%$ with seven days of fermentation tended to increase the quality of OPF, which resulted in an increase in the DM digestibility, total VFAs and $\mathrm{NH}_{3}-\mathrm{N}$ of rumen fluid in vitro. Indigenous microbes which are able to secrete multiple enzymes play a crucial role in feedstuff digestion and are also capable of converting the inorganic forms of $\mathrm{N}$ compounds into organic $\mathrm{N}$ (true protein), which can enhance $\mathrm{CP}$ availability in treated OPF-based feed. Fermentation of OPF by local microbes can also increase its digestibility and palatability and improve the vitamin and mineral contents in feedstuffs.

Ramin et al. (2008) found that in vitro fermentation of OPF with C. kwangyangense, a cellulolytic bacterium isolated from termite gut, increased the total concentration of VFAs in rumen fluids compared with that resulting from other termite bacterial strains. Endo- $\beta-1,4$-glucanase produced by termite bacteria plays a fundamental role in cellulose digestion and can concurrently enhance rumen microbial activity and ruminal metabolites (König, 2006). A selected group of probiotic strains that has a high potential to degrade lignin also appear to be essential in cellulose degradation by significantly increasing the degradability of DM in vitro, regardless of whether the rumen fluid was adapted to OPF. Mardalena and Musnandar (2019) found that in vitro fermentation of OPF fermented with $7.5 \%$ produren (a durian probiotic) enhanced DM digestibility and increased the total production of VFAs in bovine rumen fluid. Selected rumen microorganisms can actively secrete several enzymes, specifically amylase, cellulase and catalase, during fermentation that have the ability to degrade OPF into small molecules so that it can be absorbed by microbes for cell growth and concomitantly increase the concentration of byproducts, such as VFAs, available for utilisation by animals as an energy source. In the microbial fermentation process, active decomposition of the substrate occurs by the action of appropriate enzymes on indigestible materials, such as hemicelluloses and lignin, converting them into simpler carbohydrate molecules.

Several in vitro studies using exogenous fibrolytic enzyme additives in the pre-digestion of OPF have been conducted to improve the digestibility of complex fibres (Beauchemin et al., 2003; Rode et al., 1999), but the results were often inconsistent. The inconsistency in the findings of these studies stems from a variety of factors, including diet composition, type of enzyme preparation, enzyme quantity, enzyme stability, and the method of application. Enzyme additives constantly offer alternative ways for enhancing ruminant growth performance. These additives are primarily attributed to observe the improvements in ruminal fibre digestion and digestible energy intake (DEI). A study carried out by Boonthep et al. (2011) revealed that TMRs containing treated OPF ( $60 \%$ of DM) with $2 \mathrm{~g} \mathrm{~kg}^{-1} \mathrm{DM}$ fibrolytic enzymes reduced gas production without having negative effects on nutrient digestibility, suggesting that the environmental aspects (specifically, methane mitigation) of feeding ruminant animals could be improved. However, the soluble gas fraction slightly increased while the gas production rate slightly decreased in response to increases in the quantity of enzyme. The moderate application of exogenous enzyme in animal feedstuff might produce favourable, minor changes in feed surface structure either following or prior to ingestion; however, excessive enzyme use can contribute to extreme enzyme attachment to ingested feed, limiting the ability of microbial enzymes to attach to the ingested feed and thereby restricting its digestion (Nsereko et al., 2002).

The increases in total gas production and the potentially fermentable soluble fraction in vitro with OPF treated with exogenous enzyme were probably caused by the rise in the rate of rumen fermentation and the efficient digestion of feeds in the rumen. Aside from OPF, Khattab and Tawab (2018) have found that the application of date palm frond feed in combination with fibrolytic enzymes (inclusion rate of $4 \mathrm{~g} \mathrm{~kg}^{-1} \mathrm{DM}$ ) was beneficial and resulted in improvements in ruminal digestibility and fermentation. Rusli et al. (2019) used enzyme extract of Ganoderma lucidum and Lentinula edodes to measure the correlation between enzymespecific activity and in vitro rumen fermentation of OPF. Biological treatment with enzyme extract of G. lucidum and L. edodes showed a similar pattern, wherein the structural carbohydrates in OPF were degraded, and the CP content increased. However, between these two WRF, G. lucidum seemed to be more promising for improving rumen degradability in vitro.

Synergistic effects of different treatments of biomass should be considered to achieve balanced and optimal fibre digestion and fermentation in ruminants. Hassim et al. (2012) suggested that combination of chemically (e.g., $\mathrm{NH}_{3}$ ) treated fibrous matter (e.g., forage or roughage) and fibrolytic enzymes could significantly enhance the degradability of ruminal fibres in OPF in vitro compared with treatment by enzymes alone. The application of cellulase alone or in combination with lactic acid bacteria (Lactobacillus plantarum MTD1) improved the in vitro 
fermentation profile, changed the FA properties, and enhanced the nutritional value of pre-digested OPF silage (Ebrahimi et al., 2014). Biological treatment of OPF with enzyme extract of G. lucidum combined with physical treatment improved the nutritional values of OPF by decreasing the lignin content and, consequently, improving ruminal digestibility and increasing total gas production, VFAs and ARDCs (Rahman et al., 2011). Harahap et al. (2018) reported that OPF treated with the physico-chemical method using FCT combined with Indigofera sp. and urea in the rumen-simulating, semi-continuous culture system (Rusitec) could facilitate the breakdown of lignocellulose bonds and the removal of lignin from OPF which is recognised as a valuable feedstuff. The effects of treated OPF on in vitro gas production, rumen fermentation profiles and digestibility are summarised in Table 5. Treatment of OPF, which uses various techniques including $\mathrm{NH}_{3}$ fibre explosion, chemical treatment, biological treatments and steam explosion serve a similar function to alter the structure of cellulose biomass to make cellulose more accessible and susceptible to ruminal microbial to enzymatic degradation in its amorphous form (Rabemanolontsoa and Saka, 2016). However, most research mainly focused on biologically treated OPF in in vitro fermentation and digestibility studies in view of practical use of this treatment by considering significant cost effectiveness, safety, improvement of DM recovery, aerobic stability, and animal performance (Azmi et al., 2019).

\section{EFFECTS OF FEEDING TREATED OPF ON RUMINANTS}

Several studies have assessed the effects of feeding treated OPF on different ruminant livestock species under various conditions, which are described below.

\section{Effects of Feeding Treated OPF to Small Ruminants}

The feeding of small ruminants with treated OPF appears to be the most promising feeding strategy for improving their productivity in palm oil producing countries. The nutritional value of OPF for small ruminants can be enhanced by chemical and / or biological treatment, resulting in improved fibre DM biodegradability and bioavailability of energy and protein. The inclusion of treated OPF in small ruminant feed rations at the optimal level could promote feed digestibility, growth performance, meat quality and milk yield. Several studies have demonstrated the beneficial effects of feeding treated OPF on the growth performance of small ruminants, as described in Table 6. Hamchara et al. (2018) found that feeding OPF treated with various levels of L. sajor-caju to 16 month-old crossbred male goats promoted digestibility and $\mathrm{N}$ retention, indicating that the application of fungus-treated OPF provides an alternative forage feedstuff constituting up to $100 \%$ OPF. This result is consistent with the findings of Febrina et al. (2017), who showed that the best

TABLE 5. EFFECTS OF TREATED OIL PALM FROND (OPF) ON IN VITRO GAS PRODUCTION, RUMEN FERMENTATION, AND DIGESTIBILITY

\begin{tabular}{|c|c|c|c|}
\hline Treatment methods & $\begin{array}{l}\text { Inclusion level in OPF/ } \\
\text { condition }\end{array}$ & Interpretation & References \\
\hline $\begin{array}{l}\text { White-rot fungi (WRF) } \\
\text { (L. edodes and P. brevispora) }\end{array}$ & $\begin{array}{l}3 \text { or } 9 \text { weeks of fermentation } \\
\text { at } 30^{\circ} \mathrm{C}\end{array}$ & $\uparrow \mathrm{IVGP} ; \uparrow \mathrm{VFA} ; \uparrow \mathrm{ARDC}$ & Rahman et al. (2011) \\
\hline $\begin{array}{l}\text { Enzyme extract of } \\
\text { G. lucidum + physical } \\
\text { treatment }\end{array}$ & $\begin{array}{l}8 \mathrm{ml} \text { enzyme extract/ } \\
\text { incubated for five days at } 40^{\circ} \mathrm{C}\end{array}$ & $\downarrow$ lignin content; $\uparrow$ IVGP; $\uparrow$ VFA; $\uparrow$ ARDC & Rusli et al. (2019) \\
\hline $\begin{array}{l}\text { Lactobacillus plantarum }+ \\
\text { cellulose }\end{array}$ & $\begin{array}{l}1 \times 10^{6} \text { colonies forming units } \\
(\mathrm{CFU}) \mathrm{g}^{-1}\end{array}$ & $\uparrow \operatorname{IVDMD} ; \uparrow \mathrm{VFA} ; \downarrow$ fat content & Ebrahimi et al. (2014) \\
\hline $\begin{array}{l}\text { Fibrolytic enzymes isolated } \\
\text { form Aspergillus spp. }\end{array}$ & $\begin{array}{l}\text { Levels of enzyme }(0,2,4 \text { and } \\
6 \mathrm{~g} \mathrm{~kg}^{-1} \text { of DM) }\end{array}$ & $\begin{array}{l}\downarrow \text { IVGP; without having adverse effects on } \\
\text { nutrient digestibility }\end{array}$ & Boonthep et al. (2011) \\
\hline Local microorganisms & $\begin{array}{l}60 \mathrm{~g} \mathrm{~kg}^{-1} / 7 \text { days of } \\
\text { fermentation }\end{array}$ & $\begin{array}{l}\uparrow \mathrm{IVDMD} ; \uparrow \mathrm{VFA} ; \uparrow \mathrm{N} \mathrm{NH}_{3} \text { of rumen fluid } \\
\text { in vitro }\end{array}$ & Mulianda et al. (2018) \\
\hline $\begin{array}{l}\text { Cellulolytic bacterium } \\
\text { from termite gut } \\
\text { (C. kwangyangense) }\end{array}$ & $231 \times 10^{-6} \mathrm{CFU} \mathrm{ml}^{-1}, \mathrm{OD}: 0.5$ & $\begin{array}{l}\uparrow \text { IVVFA; } \uparrow \text { IVDMD; } \uparrow \text { IVOMD; improve NDF } \\
\text { and cellulose content in rumen fluids }\end{array}$ & Ramin et al. (2008) \\
\hline $\begin{array}{l}\text { Produren } \\
\text { (a durian probiotic) }\end{array}$ & $\begin{array}{l}7.5 \mathrm{~g} \% \mathrm{DM} / 1 \text { week } \\
\text { fermentation at room } \\
\text { temperature }\end{array}$ & $\uparrow \mathrm{IVDMD} ; \uparrow \mathrm{VFA}$ & $\begin{array}{l}\text { Mardalena and } \\
\text { Musnandar (2019) }\end{array}$ \\
\hline
\end{tabular}

Note: ARDC - apparent rumen degradable carbohydrate; DM - dry matter; IVDMD - in vitro dry matter digestibility; IVGP - in vitro gas production; IVOMD - in vitro organic matter digestibility; $\mathrm{NH}_{3}$ - ammonia; OD - optical density; VFA - volatile fatty acids; $\uparrow$ increase; $\downarrow$ - decrease. 
TABLE 6. EFFECTS OF TREATED OIL PALM FROND (OPF) ON RUMINANT PERFORMANCE, RUMEN FERMENTATION PROFILES, NUTRIENT DEGRADABILITY AND MILK PRODUCTION

\begin{tabular}{|c|c|c|c|c|}
\hline Ruminant type & $\begin{array}{l}\text { Treatment methods } \\
\text { of OPF }\end{array}$ & $\begin{array}{l}\text { Animals/optimal } \\
\text { inclusion level in the diet }\end{array}$ & Effects & References \\
\hline \multirow{9}{*}{$\begin{array}{l}\text { Small } \\
\text { ruminant }\end{array}$} & $\begin{array}{l}\text { Biological } \\
\text { pre-treated OPF }\end{array}$ & $\begin{array}{l}\text { Male cross-bred Boer } \\
\text { goats } / 20 \% \text { DM basis }\end{array}$ & $\begin{array}{l}\uparrow \text { UFA in longissimus dorsimuscle muscle } \\
(40.01 \%) \text { compared to untreated OPF diet }\end{array}$ & $\begin{array}{l}\text { Rusli et al. } \\
\text { (2021) }\end{array}$ \\
\hline & $\begin{array}{l}\text { White-rot fungi } \\
\text { (Lentinus sajor-caju) }\end{array}$ & $\begin{array}{l}\text { Crossbred male goats } \\
\text { (Thai Native } \times \text { Anglo }\end{array}$ & $\begin{array}{l}\uparrow \text { nitrogen }(\mathrm{N}) \text {-retention }(63.37 \% \text { based on } \\
\mathrm{g} / \mathrm{d} / \text { animal); }\end{array}$ & $\begin{array}{l}\text { Hamchara } \\
\text { et al. }(2018)\end{array}$ \\
\hline & & Nubian)/30\% DMI basis & Improved microbial-N supply; & \\
\hline & & & $\begin{array}{l}\text { DMI and nutrient intake - no changes } \\
\text { compared to untreated OPF diet }\end{array}$ & \\
\hline & $\begin{array}{l}\text { Phanerochaete } \\
\text { chrysosporium + } \\
\text { minerals (S, P and } \\
\mathrm{Mg} \text { ) }\end{array}$ & Male goats $/ 40 \%$ DM basis & $\begin{array}{l}\uparrow \text { average daily gain ( } \mathrm{g} / \mathrm{head} / \text { day) of } 60.0 \% \\
\text { and feed efficiency of } 29.25 \% \text { compared to } \\
\text { control ( } 40 \% \text { napier grass based diet); } \\
\downarrow \text { feed conversion ( } 29.27 \% \text { ) compared to } \\
\text { control ( } 40 \% \text { napier grass) }\end{array}$ & $\begin{array}{l}\text { Febrina } \\
\text { et al. }(2017)\end{array}$ \\
\hline & $\begin{array}{l}\text { OPF fermented } \\
\text { with } \\
\text { microorganisms }\end{array}$ & $\begin{array}{l}\text { Katjang goats } / 20 \% \mathrm{DM} \\
\text { basis }\end{array}$ & $\begin{array}{l}\uparrow \text { daily gain }(\mathrm{g} / \mathrm{head}) \text { of } 27.01 \% \text { compared to } \\
\text { untreated OPF; } \\
\uparrow \text { feed efficiency by } 51.93 \% \text { compared to } \\
\text { untreated OPF diet }\end{array}$ & $\begin{array}{l}\text { Astuti } \\
\text { et al. }(2017)\end{array}$ \\
\hline & $\begin{array}{l}\text { Fungal-treated } \\
\text { OPF }\end{array}$ & $\begin{array}{l}\text { Crossbred male goats } \\
\text { (Thai Native } \times \text { Anglo } \\
\text { Nubian) } / 30 \% \text { DM basis }\end{array}$ & $\begin{array}{l}\text { Growth performance, nutrient digestibility, } \\
\text { feed intake, and rumen fermentation } \\
\text { characteristics - no changes compared to } \\
\text { untreated OPF diet }\end{array}$ & $\begin{array}{l}\text { Chanjula } \\
\text { et al. (2018) }\end{array}$ \\
\hline & $\begin{array}{l}\text { Steam-treated OPF } \\
\text { supplemented with } \\
\text { urea }\end{array}$ & $\begin{array}{l}\text { Dairy goats } \\
\text { (Saanen) } / 89.2 \%-91.66 \% \\
\text { DM basis }\end{array}$ & $\begin{array}{l}\uparrow \text { digestibility of nutrients; } \\
\text { Improved ruminal fermentation, microbial } \\
\text { yield, and } \mathrm{N} \text { balance in goats fed with steam- } \\
\text { treated OPF supplemented with } 3 \% \text { urea }\end{array}$ & $\begin{array}{l}\text { Paengkoum } \\
\text { et al. }(2006)\end{array}$ \\
\hline & $\begin{array}{l}\text { Pelleted OPF } \\
\text { (physical } \\
\text { treatment) }\end{array}$ & $\begin{array}{l}\text { Male goats } / 50 \% \text { OPF } \\
\text { pellet }\end{array}$ & $\begin{array}{l}\uparrow \text { apparent DM digestibility (13\%) and } \\
\text { apparent CP digestibility (58\%) compared to } \\
\text { untreated OPF diet }\end{array}$ & Dahlan (2000) \\
\hline \multirow{8}{*}{$\begin{array}{l}\text { Large } \\
\text { ruminant }\end{array}$} & $\begin{array}{l}\text { Fermented OPF } \\
\text { with prolinas } \\
\text { (pineapple skin } \\
\text { probiotic) }\end{array}$ & $\begin{array}{l}\text { Lactating Friesian Holstein } \\
\text { Crossbred (PFH) dairy } \\
\text { cattle } / 22 \% \text { DM basis }\end{array}$ & $\begin{array}{l}\downarrow \text { feed consumption ( } 11.87 \% \text { ) compared to } \\
\text { control (diet containing forage); } \\
\downarrow \text { milk production (litre/ day) of } 17.33 \% \\
\text { compared to control treatment }\end{array}$ & $\begin{array}{l}\text { Mardalena } \\
\text { et al. }(2019)\end{array}$ \\
\hline & d OPF & Bali bulls / $50 \%$ DM basis & $\begin{array}{l}\uparrow \text { carcass weight }(\mathrm{CW}) \text {, rib-eye muscle area } \\
\text { (REMA), and meat chemical compared to a } \\
\text { diet without } \mathrm{NH}_{3} \text {-treated OPF }\end{array}$ & $\begin{array}{l}\text { Muthalib and } \\
\text { Afdal (2018) }\end{array}$ \\
\hline & $\begin{array}{l}\text { Sodium hydroxide } \\
(\mathrm{NaOH}) \text {-treated }\end{array}$ & $\begin{array}{l}\text { Kedah-Kelantan cross } \\
\text { calves } / 40 \% \text { DM basis }\end{array}$ & $\begin{array}{l}\uparrow \mathrm{DM} \text { digestibility and DMI compared to } \\
\text { untreated and OPF silage }\end{array}$ & $\begin{array}{l}\text { Kawamoto } \\
\text { et al. }(2001)\end{array}$ \\
\hline & Urea treated OPF & $\begin{array}{l}\text { Sahiwal-Friesian lactating } \\
\text { dairy cows } / 30 \% \text { DM basis }\end{array}$ & $\begin{array}{l}\downarrow \text { DMI (kg/day) of } 21.98 \% \text { compared to } \\
\text { untreated OPF diet; }\end{array}$ & $\begin{array}{l}\text { Ishida and Abu } \\
\text { Hassan (1997) }\end{array}$ \\
\hline & & & $\begin{array}{l}4 \% \text { FCM: ME intake ratio not different } \\
\text { between the untreated OPF and 30\% urea- } \\
\text { treated OPF silage; }\end{array}$ & \\
\hline & & & $\begin{array}{l}\text { Yield of } 4 \% \text { FCM ( } \mathrm{kg} / \text { day) - no changes } \\
\text { compared to untreated OPF diet }\end{array}$ & \\
\hline & Urea treated OPF & $\begin{array}{l}\text { Kedah- Kelantan bulls/ } \\
3 \% \text { urea treated OPF }\end{array}$ & $\begin{array}{l}\uparrow \mathrm{TDN}(7.5 \%) \text { compared to } 0 \% \text { urea treated } \\
\text { OPF; }\end{array}$ & $\begin{array}{l}\text { Ishida and Abu } \\
\text { Hassan (1992) }\end{array}$ \\
\hline & & & Improved DMI & \\
\hline
\end{tabular}

Note: CP - crude protein; DM - dry matter; FCM - fat-corrected milk; ME - metabolisable energy; $\mathrm{NH}_{3}$ - ammonia; TDN - total digestabile nutrients; UFA - unsaturated fatty acid; $\uparrow$ - increase; $\downarrow$ - decrease. 
diet for goats, as indicated by body weight gain and low feed conversion, was OPF fermented with Phanerochaete chrysosporium plus minerals (S, P and $\mathrm{Mg}$ ). The inclusion of minerals could support the growth of $P$. chrysosporium and enhance the activity of fungal ligninolytic enzymes. However, Chanjula et al. (2017) observed no significant difference in feed intake, performance, carcass traits, or meat quality in finishing crossbred male goats (Thai Native $\times$ Anglo Nubian) fed TMRs containing 30\% OPF treated with L. sajor-caju.

Astuti et al. (2017) demonstrated that a diet containing at least $20 \%$ fermented OPF enhanced the $\mathrm{N}$ balance, feed efficiency, and growth response in Katjang goats. Likewise, Chanjula et al. (2018) suggested that feeding 30\% fungal-treated OPF (FTOPF) in TMRs to crossbred (Thai Native $\times$ Anglo Nubian) male goats resulted in no undesired harmful effects on nutrient digestibility, feed intake, and rumen fermentation characteristics, thereby suggesting that FTOPF can be used as an alternative feed source for small ruminants. Wahyuni (2012) reported that feeding goats TMRs containing OPF silage supplemented with enzymes at $2 \mathrm{~g} \mathrm{~kg}^{-1} \mathrm{DM}$ could increase the supply of slowly fermentable carbohydrate fractions and help maintain their body weights. When lambs were given steam-treated OPF supplemented with up to $16 \mathrm{~g}$ urea $\mathrm{kg}^{-1} \mathrm{OPF}$, the DM intake (DMI), OM intake, and DM digestibility then showed significant linear $(p<0.001)$ increases (Bengaly et al., 2010). Paengkoum et al. (2006) found that feeding high energy levels (16.20-16.24 $\left.\mathrm{MJ} \mathrm{kg}^{-1}\right)$ of steam-treated OPF could improve the utilisation of urea (optimal level of 3\%) supplementation in Saanen goat feedstuff, which revealed positive responses of animal performance in conjunction with improved ruminal fermentation, microbial yield, and $\mathrm{N}$ balance. Ebrahimi et al. (2015) reported that goats fed with 50\% OPF silage with feed pellet showed promise in modulating the rumen environment so that the bio-hydrogenation of fatty acids could be decreased by rumen microbes. In ruminants, modification of FA profiles is mainly needed to regulate the antimicrobial activity of potential free fatty acids and to control microbial bio-hydrogenation to improve the nutritional value of animal feed (Jenkins et al., 2008). The supplementation of OPF ensiled with lactic acid bacteria, and cellulose enzyme increases the n-3 polyunsaturated fatty acids in the plasma and subcutaneous fat in sheep, which in turn have less negative effects on consumers' health (Ebrahimi et al., 2015).

\section{Effects of Feeding Treated OPF on Beef Cattle and Dairy Cows}

Treated OPF roughage for use in TMRs could provide an effective way to improve nutrient utilisation to enhance the growth response and reduce the costs of feeding large ruminants (e.g., cattle and buffaloes). Previous studies have reported numerous positive effects of treated OPF supplementation on some characteristics (performance, digestion, and microbial populations) of beef and dairy cattle as described in Table 6 (Ishida and Abu Hassan, 1992; 1997; Kawamoto et al., 2001; Mardalena et al., 2019; Mhudmhan et al., 2012; Muthalib and Afdal, 2018). In addition, several in vivo studies have reported that the incorporation of treated OPF with different feed additives improves the nutrient degradability of large ruminants (Kawamoto et al., 2001; Muthalib and Afdal, 2018). However, there are very few studies which have reported the effects of feeding biologically treated OPF to ruminants, including the use of fungal and exogenous fibrolytic enzyme treated OPF on in vivo digestibility in cattle (Mardalena et al., 2019). Indeed, treatment of OPF with NPN such as anhydrous $\mathrm{NH}_{3}$, urea, or other $\mathrm{NH}_{3}$-releasing compounds has been widely investigated as value-added ruminant feedstuffs for cattle and dairy cows. In addition, urea-treated OPF has been found to be effective in improving in vivo DM and CP degradability, and reducing the amount of supplemental $\mathrm{N}$, and enhancing acceptability and voluntary intake of the treated OPF by ruminants (Ishida and Abu Hassan, 1992; 1997; Muthalib and Afdal, 2018).

The feeding of mixed rations consisting of up to $30 \%$ OPF treated with $3 \%$ urea with PKC-based concentrates to beef bulls (Australian Commercial Cross bulls - 6 bulls/treatment) did not adversely affect the growth performance or the quality of lean meat. However, body weight gain, feed intake, and carcass fat decreased as the quantity of OPF treated with 3\% urea in the diet increased (Ishida and Abu Hassan, 1997). In another experiment, Ishida and Abu Hassan (1992) carried out digestion trials using Kedah-Kelantan bulls (the indigenous breed of cattle in Malaysia), to evaluate the nutritional value of OPF silage and the effects of different levels of urea inclusion on the nutritional value of OPF silage. The intake and digestibility data indicated that the nutritional value of OPF silage was high with the inclusion of 3\% urea. However, the OPF digestibility in the $6 \%$ urea treatment had decreased by nutrient losses caused by prolonged bacterial activity. The addition of urea in OPF and the optimum inclusion level could increase the $\mathrm{CP}$ level and formation of $\mathrm{NH}_{3}$ in rumen, which stimulates urea-splitting bacterial growth and the subsequent production of larger quantities of VFAs through ruminal fermentation. These findings suggest that treated OPF silage forage can be used as a potential feedstuff to meet the nutritional needs of beef cows.

A feeding trial conducted by Muthalib and Afdal (2018) demonstrated that OPF treated with $50 \% \mathrm{NH}_{3}$ tended to increase carcass weight, rib-eye muscle 
area (REMA) and the meat chemical content of Bali bulls. Mhudmhan et al. (2012) observed that OPF silage mixed with $2 \%, 4 \%$ or $6 \%$ molasses positively impacted the nutritional utilisation and rumen fermentation profile in Thai native male cattle when they were fed a concentrate at $0.5 \%$ of mature cattle BW. Kawamoto et al. (2001) reported that sodium hydroxide $(\mathrm{NaOH})$-treated OPF had a higher DM digestibility and digestible DMI in cattle compared with that of OPF pellets and silage, although it had low palatability. It was suggested that the low fermentation quality might reduce the palatability of $\mathrm{NaOH}$ treated OPF silage based on animal feeding trials. The inclusion of nutritious alkali-treated OPF in the concentrate or roughage component of the complete feed has proved to be beneficial for promoting growth performance and improving digestibility, N-balance, and rumen fermentation of beef cattle. However, since $\mathrm{NaOH}$ is caustic and dangerous, a safer procedure for treatment and a more cost-effective method should be developed.

Feeding of treated OPF to dairy animals has variable effects on milk composition. OPF silage (solid-state fermentation of OPF without additives) made of fresh OPF could be fed to lactating dairy cows as a roughage source without adverse effects on animal condition or milk flavour. The optimum level of inclusion of OPF silage in the diet is approximately $30 \%$ (on a DM basis). Ishida and Hassan (1997) found that Sahiwal-Friesian lactating dairy cows fed $30 \%$ OPF (on a DM basis) silage as roughage with concentrate consisting of corn- and soybean-based feed produced the highest yields of milk and did not appear to have any adverse effects in terms of condition or milk flavour relative to those fed a diet of 50\% OPF silage or $50 \%$ fodder. The results obtained indicated that OPF silage could be fed to lactating dairy cows for milk production. Similarly, Mardalena et al. (2019) found that corn straw substitution with fermented OPF with prolinas (pineapple skin probiotic) in lactating Friesian Holstein Crossbred (PFH) dairy cattle feed could decrease feed consumption but not adversely affecting feed efficiency and $4 \%$ fat corrected milk (FCM), milk composition and production of dairy cattle. Ishida and Abu Hassan (1992) suggested that feeding dairy cattle with OPF silage treated with optimum urea level could increase the level of protein content in milk and alter milk composition.

\section{CONCLUSION}

OPF is identified as the major biomass source used as feedstuffs for ruminants in the tropics as a substitute for tropical grasses. Its utilisation as a livestock feed is limited due to poor nutritive values with low ME and high lignocellulosic content. Therefore, OPF treatment is a crucial step for the conversion of OPF into value-added feedstuffs. Extensive investigations have been carried out on the effects of different treatment methods on OPF, nutritional value, and chemical compositions. Analysis of various treatment methods brings us to the conclusion that each technique has shown promising results in relation to breakdown and altering the structure of lignocellulose in OPF to make lignocellulosic substrates readily accessible to enzymatic hydrolysis by rumen microbes, thereby increasing in vitro and in vivo rumen apparent DM and organic matter degradability and improving ruminant growth efficiency. Although there have already been several laboratory studies (in vitro and in sacco experiments) and on-farm trials, most research works have been carried out separately. Thus, there is still a limited systematic literature review on OPF treatment from laboratory to production. Moreover, the molecular approaches evaluating the effects of treated OPF as value-added feedstuffs in ruminant in associated expression patterns of growth performance and digestibility efficacy-related genes are still lacking. Therefore, further study is needed to determine how treated OPF may affect ruminant metabolism activities by regulating the transcription and translation of their DNA.

Although different biological, chemical, and physical treatments of OPF have been used to improve digestibility and feed intake of ruminant animals, the practical use of these treatments can be restricted by significant cost-effectiveness, energy-effectivity, environmental sustainability, and safety. Therefore, the question related to sustainable agriculture arises what strategies can be technically and socio-economically suitable and acceptable to farmers under local conditions. Biological treatment (i.e., fungi and enzymes treatments) is considered a favourable option due to its practicality, environmental-friendly and safer approach for enhancing the nutritional value of OPF as animal feed. Thus, the biological treatment method could offer an optimisation approach in contributing to sustainable agriculture, particularly in ruminant production using OPF waste from oil palm plantations. Furthermore, ligninolytic enzymes combined with non-protein $\mathrm{N}$ sources such as urea or $\mathrm{NH}_{3}$ could be an alternative way to shorten the silage incubation period or the delignification cycle. In conclusion, to date, the fundamental factor contributing to the lack of technology in producing a large number of fungi or enzymes is the difficulty in controlling the optimum environmental conditions that lead to problems in biological treatments procedure in commercial or small-scale farms. In this respect, future research should focus on optimisation of biological and economic effects of different treatments and development in alternative enzyme production technology for an effective OPF treatment. 


\section{ACKNOWLEDGEMENT}

The authors would like to thank the Director-General of MPOB for permission to publish this article.

\section{REFERENCES}

Abd El Tawab, A M; Matloup, O H; Kholif, A M; Abo El-Nor, S A H; Murad, H A; El-Sayed, H M and Khorshed, M M (2015). Influence of addition of tannase enzyme to reducing tannins effects in lactating goats diets. Int. J. Dairy Sci., 10: 24-35.

Agensi Inovasi Malaysia (2013). National biomass strategy 2020: New wealth creation for Malaysia's biomass industry. https://www.cmtevents.com/ MediaLibrary/BStgy2013RptAIM.pdf, accessed on 25 November 2021.

Aiman-Zakaria, A; Yong-Meng, G; Ali-Rajion, M; Jafari, S; Faseleh-Jahromi, M; Shokriyazdan, $\mathrm{P}$ and Ebrahimi, M (2017). The influence of plant polyphenols from oil palm (Elaeis guineensis Jacq.) leaf extract on fermentation characteristics, biohydrogenation of C18 PUFA, and microbial populations in rumen of goats: In vitro study. Acta Agric. Scand. A-Anim. Sci., 67: 76-84.

Astuti, T; Santoso, U and Amir, Y (2017). Nutritional value of fermented palm oil fronds as a basis for complete feed for ruminants. Pak. J. Nutr., 16: 96-100.

Awalludin, M F; Sulaiman, O; Hashim, R and Nadhari, W N A W (2015). An overview of the oil palm industry in Malaysia and its waste utilization through thermochemical conversion, specifically via liquefaction. Renew. Sust. Energ. Rev., 50: 1469-1484.

Azmi, M A; Yusof, M T; Zunita, Z and Hassim, H A (2019). Enhancing the utilization of oil palm fronds as livestock feed using biological pre-treatment method. IOP Conf. Ser. Earth Environ. Sci. Universitas Brawijaya, East Java, Indonesia. Vol. 230, No. 1. p. 012077.

Barlianti, V; Dahnum, D; Hendarsyah, H and Abimanyu, H (2015). Effect of alkaline pretreatment on properties of lignocellulosic oil palm waste. Procedia Chem., 16: 195-201.

Beauchemin, K A; Colombatto, D; Morgavi, D P and Yang, W Z (2003). Use of exogenous fibrolytic enzymes to improve feed utilization by ruminants. J. Anim. Sci., 81: E37-E47.

Beigh, Y A; Ganai, A M and Ahmad, H A (2017). Prospects of complete feed system in ruminant feeding: A review. Vet. World., 10: 424-437.
Bengaly, K; Liang, J B; Jelan, Z A; Ho, Y W and Ong, H K (2010). Utilization of steam-processed oil palm (Elaeis guineensis) frond by ruminants in Malaysia: Investigations for nitrogen supplementation. Afr. J. Agric. Res., 5: 2131-2136.

Binod, P; Satyanagalakshmi, K; Sindhu, R; Janu, K U; Sukumaran, R K and Pandey, A (2012). Short duration microwave assisted pretreatment enhances the enzymatic saccharification and fermentable sugar yield from sugarcane bagasse. Renew. Energy, 37: 109-116.

Boonthep, K; Ngampongsai, W; Wattanachant, C; Visessanguan, W and Boonpayung, S (2011). Effects of enzyme levels in total mixed ration containing oil palm frond silage on kinetics of gas production. In SAADC 2011 strategies and challenges for sustainable animal agriculture-crop systems, Volume III: full papers. Proc. of the $3^{\text {rd }}$ International Conference on Sustainable Animal Agriculture for Developing Countries. Nakhon Ratchasima, Thailand. p. 563-567.

Chanjula, P; Petcharat, V and Cherdthong, A (2017). Effects of fungal (Lentinus sajor-caju) treated oil palm frond on performance and carcass characteristics in finishing goats. Asian-Australas. J. Anim. Sci., 30: 811818.

Chanjula, P; Petcharat, V and Cherdthong, A (2018). Rumen characteristics and feed utilization in goats fed with biologically treated oil palm fronds as roughage in a total mixed ration. S. Afr. J. Anim. Sci., 48: 1049-1056.

Chanjula, P; Petcharat, V and Promkot, C (2015). Nutritive value of oil palm fronds treated with white rot fungi. Proc. of the $5^{\text {th }}$ International Conference on Sustainable Animal Agriculture for Developing Countries. Dusit Thani Pattaya Hotel, Thailand. p. 135-138.

Curiel, J A; Rodríguez, H; Acebrón, I; Mancheño, J M; De Las Rivas, B and Muñoz, R (2009). Production and physicochemical properties of recombinant Lactobacillus plantarum tannase. J. Agric. Food Chem., 57: 6224-6230.

Dahlan, I (2000). Oil palm frond: A feed for herbivores. Asian-Aus. J. Anim. Sci., 13: 300-303.

Dahlan, I; Yamada, Y and Mahyuddin, M D (1993). Botanical composition and models of metabolizable energy availability from undergrowth in oil palm plantations for ruminant production. Agroforest. Syst., 24: 233-246.

Ebrahimi, M; Rajion, M A; Goh, Y M; Farjam, A S; Sazili, A Q and Schonewille, J T (2014). The effects 
of adding lactic acid bacteria and cellulase in oil palm (Elaeis guineensis Jacq.) frond silages on fermentation quality, chemical composition and in vitro digestibility. Ital. J. Anim. Sci., 13: 557-562.

Ebrahimi, M; Rajion, M A; Meng, G Y; Shokryzadan, P; Sazili, A Q and Jahromi, M F (2015). Feeding oil palm (Elaeis guineensis Jacq.) fronds alters rumen protozoal population and ruminal fermentation pattern in goats. Ital. J. Anim. Sci., 14: 3877.

Febrina, D; Jamarun, N and Zain, M (2014). Biological delignification by Phanerochaete chrysosporium with addition of mineral $\mathrm{Mn}$ and its effect on nutrient content of oil palm frond. Proc. of the $16^{\text {th }}$ AAAP Animal Science Congress Vol. II. Yogyakarta, Indonesia. p. 1723-1726.

Febrina, D; Jamarun, N; Zain, M and Khasrad (2016). Effects of calcium (Ca) and manganese (Mn) supplementation during oil palm frond fermentation by Phanerochaete chrysosporium on in vitro digestibility and rumen fluid characteristics. Pak. J. Nutr., 15: 352-358.

Febrina, D; Jamarun, N; Zain, M and Khasrad (2017). Effects of using different levels of oil palm fronds (FOPFS) fermented with Phanerochaete chrysosporium plus minerals $(\mathrm{P}, \mathrm{S}$ and $\mathrm{Mg}$ ) instead of napier grass on nutrient consumption and the growth performance of goats. Pak. J. Nutr., 16: 612-617.

Galbe, M and Zacchi, G (2012). Pretreatment: The key to efficient utilization of lignocellulosic materials. Biomass Bioenergy, 46: 70-78.

Garrote, G; Domínguez, H and Parajó, J C (1999). Hydrothermal processing of lignocellulosic materials. Holz als Roh- und Werkstoff., 57: 191-202.

Gunun, N; Wanapat, M; Gunun, P; Cherdthong, A; Khejornsart, P and Kang, S (2016). Effect of treating sugarcane bagasse with urea and calcium hydroxide on feed intake, digestibility, and rumen fermentation in beef cattle. Trop. Anim. Health Prod., 48: 1123-1128.

Hamchara, P; Chanjula, P; Cherdthong, A and Wanapat, M (2018). Digestibility, ruminal fermentation and nitrogen balance with various feeding levels of oil palm fronds treated with Lentinus sajor-caju in goats. Asian-Australas. J. Anim. Sci., 31: 1619-1626.

Harahap, R P; Jayanegara, A; Nahrowi and Fakhri, S (2018). Evaluation of oil palm fronds using fiber cracking technology combined with Indigofera sp. in ruminant ration by Rusitec. AIP Conf. Proc. 2021. AIP Publishing LLC. p. 050008.
Hassim, H A; Lourenço, M; Goh, Y M; Baars, J J P and Fievez, V (2012). Rumen degradation of oil palm fronds is improved through pre-digestion with white rot fungi but not through supplementation with yeast or enzymes. Can. J. Anim. Sci., 92: 79-87.

Hermiati, E; Anita, S; Risanto, L; Styarini, D; Sudiyani, Y; Hanafi, A and Abimanyu, H (2013). Biological pretreatment of oil palm frond fibre using white-rot fungi for enzymatic saccharification. Makara J. Technol., 17: 39-43.

Hong, L S; Ibrahim, D and Omar, I C (2012). Oil palm frond for the production of bioethanol. Int. J. Biochem Biotechnol., 1: 7-11.

Ishida, M and Abu Hassan, O (1992). Effect of urea treatment level on nutritive value of oil palm fronds silage in Kedah-Kelantan bulls. Proc. of the $6^{\text {th }}$ AAAP Animal Science Congress. Vol. III. Kasetsart University, Bangkok, Thailand. p. 68.

Ishida, M and Abu Hassan, O (1997). Utilization of oil palm frond as cattle feed. Jpn. Agric. Res. Q., 31: 41-47.

Jaffri, J M; Mohamed, S; Ahmad, I N; Mustapha, N M; Manap, Y A and Rohimi, N (2011). Effects of catechin-rich oil palm leaf extract on normal and hypertensive rats' kidney and liver. Food Chem., 128: 433-441.

Jayanegara, A; Ardhisty, N F; Dewi, S P; Antonius; Ridwan, R; Laconi, E B; Nahrowi and Ridla, M (2019). Enhancing nutritional quality of oil palm empty fruit bunch for animal feed by using fibre cracking technology. Adv. Anim. Vet. Sci., 7: 157163.

Jenkins, T C; Wallace, R J; Moate, P J and Mosley, E E (2008). Board-invited review: Recent advances in biohydrogenation of unsaturated fatty acids within the rumen microbial ecosystem. J. Anim. Sci., 86: 397-412.

Kawamoto, H; Mohamed, W Z; Mohd Shukur, N I; Mohd Ali, M S; Ismail, Y and Oshio, S (2001). Palatability, digestibility and voluntary intake of processed oil palm fronds in cattle. Jpn. Agric. Res. Q., 35: 195-200.

Khattab, M S A and Tawab, A M A E (2018). In vitro evaluation of palm fronds as feedstuff on ruminal digestibility and gas production. Acta Sci-Anim. Sci., 40: e39586.

König, H (2006). Bacillus species in the intestine of termites and other soil invertebrates. J. Appl. Microbiol., 101: 620-627. 
Kristiani, A; Abimanyu, H; Setiawan, A H and Aulia, F (2013). Effect of pretreatment process by using diluted acid to characteristic of oil palm's frond. Energy Procedia, 32: 183-189.

Kum, W H and Zahari, M W (2011). Utilisation of oil palm by-products as ruminant feed in Malaysia. J. Oil Palm Res., 23: 1029-1035.

Kushairi, A; Ong-Abdullah, M; Nambiappan, B; Hishamuddin, E; Bidin, M N I Z; Ghazali, R; Subramaniam, V; Sundram, S and Parveez, G K A (2019). Oil palm economic performance in Malaysia and R\&D progress in 2018. J. Oil Palm Res., 31: 165194.

Mardalena and Musnandar, E (2019). In vitro evaluation of oil palm fronds fermented with produren: A durian probiotic. Pak. J. Nutr., 18: 186-196.

Mardalena, M; Syarif, S and Zubaidah, Z (2019). The effect oil palm fronds fermented with prolinas to milk production of dairy cattle. IOP Conf. Ser.: Earth Environ. Sci. Purwokerto, Indonesia. p. 012016.

Mathius, I W (2008). Development of beef cattle based palm oil industry. Develop. Agr. Innov. 1, 3: 206-224.

Meng, G Y; Rajion, M A; Jafari, S and Ebrahimi, M (2018). Oil palm frond supplementation can change fatty acid composition of rumen fluid, muscle tissue and blood cholesterol level in crossbred male sheep. Thai J. Vet. Med., 48: 137-146.

Mhudmhan, S; Wattanachant, C; Ngampongsai, W and Kuprasert, S (2012). Effects of oil palm frond silage mixed with different levels of molasses on intake and nutrient utilization in native cattle. Khon Kaen Agr. J., 40: 79-92.

Mosier, N; Wyman, C; Dale, B; Elander, R; Lee, Y Y; Holtzapple, M and Ladisch, M (2005). Features of promising technologies for pretreatment of lignocellulosic biomass. Bioresour. Technol., 96: 673-686.

Mulianda, R; Tafsin, M; Hanafi, N D and Yulinas (2018). Utilizing local microorganisms with different dosages and duration of fermentation towards digestibility and rumen activity of oil palm frond in vitro. E3S Web Conf., 52. p. 00036.

Muthalib, R A and Afdal, M (2018). Effect of oil palm frond treated with ammonia on some carcass traits and meat chemical composition of Bali bullsIndonesia. Iraqi J. Vet. Sci., 32: 57-60.

Namoolnoy, P; Phoolphundh, S and Wongwicharn A (2011). Biodegradation of lignin in oil palm fronds by white rot fungi. Kasetsart J. (Nat. Sci.), 45: 254-259. Noparat, P; Prasertsan, P; O-Thong, S and Pan, $X$ (2015). Dilute acid pretreatment of oil palm trunk biomass at high temperature for enzymatic hydrolysis. Energy Procedia, 79: 924-929.

Nsereko, V L; Beauchemin, K A; Morgavi, D P; Rode, L M; Furtado, A F; McAllister, T A; Iwaasa, A D; Yang, W Z and Wang, Y (2002). Effect of a fibrolytic enzyme preparation from Trichoderma longibrachiatum on the rumen microbial population of dairy cows. Can. J. Microbiol., 48: 14-20.

Okano, K; Iida, Y; Samsuri, M; Prasetya, B; Usagawa, $\mathrm{T}$ and Watanabe, $\mathrm{T}$ (2006). Comparison of in vitro digestibility and chemical composition among sugarcane bagasses treated by four white-rot fungi. Anim. Sci. J., 77: 308-313.

Ooi, Z X; Teoh, Y P; Kunasundari, B and Shuit, S H (2017). Oil palm frond as a sustainable and promising biomass source in Malaysia: A review. Environ. Prog. Sustainable Energy, 36: 1864-1874.

Paengkoum, P; Liang, J B; Jelan, Z A and Basery, M (2006). Utilization of steam-treated oil palm fronds in growing Saanen goats: II. Supplementation with energy and urea. Asian-Australas. J. Anim. Sci., 19: 1623-1631.

Patra, A K and Saxena, J (2011). Exploitation of dietary tannins to improve rumen metabolism and ruminant nutrition. J. Sci. Food Agric., 91: 24-37.

Pazarlioglu, N K; Urek, R O and Ergun, F (2005). Biodecolourization of Direct Blue 15 by immobilized Phanerochaete chrysosporium. Process Biochem., 40: 1923-1929.

Rabemanolontsoa, H and Saka, S (2016). Various pretreatments of lignocellulosics. Bioresour. Technol., 199: 83-91.

Rahman, M M; Lourenço, M; Hassim, H A; Baars, J J P; Sonnenberg, A S M; Cone, J W; De Boever, J and Fievez, V (2011). Improving ruminal degradability of oil palm fronds using white rot fungi. Anim. Feed Sci. Technol., 169: 157-166.

Rajion, M A; Goh, Y M; Dahlan, I and Abdullah, A S (2001). Dietary manipulation and increase in plasma unsaturated fatty acids in sheep. Asian-Australas. J. Anim. Sci., 14: 1073-1077.

Ramin, M; Alimon, A R; Panandam, J M; Sijam, K; Javanmard, A and Abdullah, N (2008). Digestion of rice straw and oil palm fronds by microflora from rumen and termite bacteria, in vitro. Pak. J. Biol. Sci., 11: 583-588. 
Rizal, N F A A; Ibrahim, M F; Zakaria, M R; Abd-Aziz S; Yee P L and Hassan, M A (2018). Pre-treatment of oil palm biomass for fermentable sugars production. Molecules., 23: 1381.

Rode, L M; Yang, W Z and Beauchemin, K A (1999). Fibrolytic enzyme supplements for dairy cows in early lactation. J. Dairy Sci., 82: 2121-2126.

Rusli, N D; Azmi, M A; Mat, K; Hasnita, C H; WanZahari, M; Azhar, K; Zamri-Saad, M and Hassim, H A (2019). The effect of physical and biological pretreatments of oil palm fronds on in vitro ruminal degradability. Pertanika J. Trop. Agric. Sci., 42: 791-805.

Rusli, N D; Mat, K; Hasnita, C H; Rahman, M M; Yusof, M T; Zamri-Saad, M and Hassim, H A (2021). Fatty acid profile of meat goats fed pre-treated oil palm frond. IOP Conf. Ser.: Earth Environ. Sci., 756: 012018.

Saminathan, M; Ramiah, S K; Gan, H M; Abdullah, N; Wong, C M V L; Ho, Y W and Idrus, Z (2019). In vitro study on the effects of condensed tannins of different molecular weights on bovine rumen fungal population and diversity. Ital. J. Anim. Sci., 18: 1451-1462.

Saminathan, M; Sieo, C C; Gan, H M, Ravi, S; Venkatachalam, K; Abdullah, N; Wong, C M V L and Ho, Y W (2016). Modulatory effects of condensed tannin fractions of different molecular weights from a Leucaena leucocephala hybrid on the bovine rumen bacterial community in vitro. J. Sci. Food Agric., 96: 4565-4574.

Soh, K L; Mohd, A K and Nurul, B (2018). Optimisation of process conditions for ethanol production from enzymatically saccharified empty fruit bunch using response surface methodology (RSM). J. Oil Palm Res., 30: 642-654.
Sujani, S and Seresinhe, R T (2015). Exogenous enzymes in ruminant nutrition: A review. Asian J. Anim. Sci., 9: 85-99.

Tafsin, M; Khairani, Y and Hanafi, N D (2018). In vitro digestibility of oil palm frond treated by local microorganism (MOL). IOP Conf. Ser.: Earth Environ. Sci., International Conference on Agriculture, Environment and Food Security. Medan, Indonesia. 122012134.

Wahyuni, R D (2012). Effect of enzyme supplementation in total mixed ration containing oil palm frond silage on productive performance of goat. Ph.D thesis, Prince of Songkla University.

Wan Zahari, M; Abu Hassan, O; Wong, H K and Liang, J B (2003). Utilization of oil palm frond-based diets for beef and dairy production in Malaysia. Asian-Australas. J. Anim Sci., 16: 625-634.

Wu, H; Zhou, Z; Yang, Y and Meng, Q (2020). Effect of steam explosion of oil palm frond and empty fruit bunch on nutrient composition and ruminal fermentation characteristics. Trop. Anim. Health Prod., 52: 1223-1228.

Yunilas, Y; Warly, L; Marlida, Y and Riyanto, I (2014). Quality improvement of oil palm wastebased feed product through indigenous microbial fermentation to reach sustainable agriculture. Int. J. Adv. Sci. Eng. Inf. Technol., 4: 282-285.

Zakaria, M R; Fujimoto, S; Hirata, S and Hassan, M A (2014). Ball milling pretreatment of oil palm biomass for enhancing enzymatic hydrolysis. Appl. Biochem. Biotechnol., 173: 1778-1789.

Zhang, Z and Zhao, Z K (2010). Microwave-assisted conversion of lignocellulosic biomass into furans in ionic liquid. Bioresour. Technol., 101: 1111-1114. 